\title{
Penerapan Kaidah Fikih Tentang Niat “Al-Umūru bi Maqūṣidihā" Dalam Kasus Hukum Tindak Pidana Pembunuhan
}

\author{
Armaya Azmi, \\ Penghulu Muda pada KUA Kec. Binjai Utara
}

\begin{abstract}
The discourse about "niat (intention)" is a fairly general study in the literature of Islamic studies, this is due to the urgency of the position of intention in human law. One of the principles of fiqh formulated about intention is "Al-Umūru bi Maqāsisidihā". This rule is the Asasiyah Rule (basic) in the discussion themes of Al-Qawa'id Al-Fiqhiyyah. So far, the study of intention is only focused on matters of worship such as salat, fasting, etc. In this article the author tries to actualize the application of the principles of fiqh in a criminal case of murder, about how the position of intent and its application in the crime of murder, how to prove intention in legal matters, and how the influence of intentions on the judge's decision. This article will also be juxtaposed with the application of the principles of fiqh about intentions towards criminal law cases in the perspective of Islamic law and criminal law, which turned out to have many conformities.
\end{abstract}

\section{Kata Kunci : Kaidah Fikih, Niat, Tindak Pidana Pembunuhan}

\section{A. Pendahuluan}

Niat merupakan hal yang memiliki kedudukan penting dalam kajian Islam, khususnya kajian hukum Islam. Dengan sebab niat, seseorang bisa mendapatkan ganjaran pahala atau justru terjatuh dalam perbuatan dosa, bahkan seseorang bisa dikategorikan sebagai orang berdosa meskipun melakukan ibadah, Misalnya seseorang yang melakukan shalat, seharusnya ia mendapatkan pahala dari ibadahnya, tapi dengan sebab niatnya ingin dipuji oleh orang lain maka justru ia diklaim sebagai orang yang melakukan syirik. Sebaliknya pula, seseorang akan dapat mendapatkan pahala hanya dengan berniat, meskipun ia belum sempat melakukan suatu pekerjaan. Seperti seorang yang berniat ingin shalat tengah malam, tapi ia tertidur sampai pagi, maka ia mendapatkan pahala shalat malam. Dalam hadis yang diriwayatkan Nasa'i, dari Abu Darda', Rasulullah bersabda :

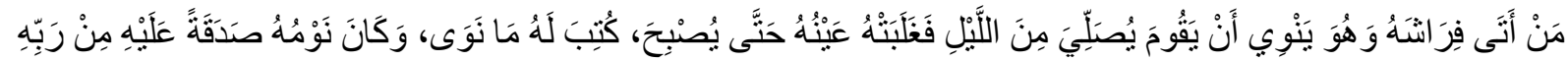
Artinya " barang siapa yang naik ke atas tempat tidurnya dengan berniat untuk bangun shalat pada malam hari, kemudian ia tertidur sampai pagi, maka dicatatkan untuknya apa yang ia niatkan, sedangkan tidurnya dinilai sebagai sedekah dari Tuhannya." ${ }^{1}$

Dari urgensi niat tersebut, maka lahirlah kaidah-kaidah fikih yang dirumuskan para ulama tentang kedudukan niat, Ibnu Nujaim merumuskan sebuah kaidah “" tidak

\footnotetext{
${ }^{1}$ Al-Nasa'i, Al-Sunan Al-Kubra, (Beirut : Muassasah Al-Risalah, 2001), Juz 2, h. 178
} 
ada pahala kecuali dengan niat'. ${ }^{2}$ Kemudian kaidah fikih yang paling populer tentang niat

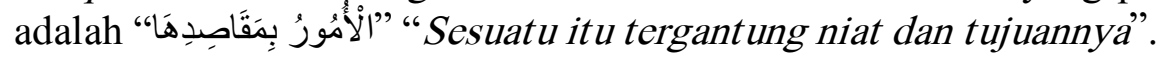

Kaidah ini merupakan kaidah dasar yang disepakati para ahli hukum Islam, berdasarkan

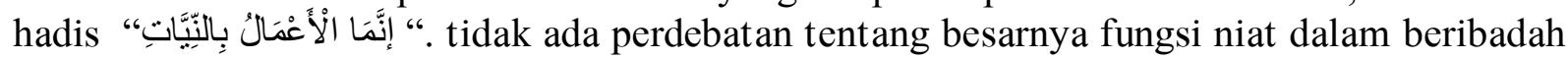
kepada Allah. Namun, karena posisi niat ini letaknya di dalam hati, yang menjadi permasalahan adalah dimana sebenarnya posisi dan kedudukan niat ini ketika dihadapkan vis a vis pada kasus hukum yang lebih dominan pada pembuktian secara empiris, bagaimana penerapannya dalam permasalahan hukum, misalnya kasus hukum tindak pidana pembunuhan, bagaimana seorang hakim bisa membuktikan niat seorang yang membunuh, apakah ada pengaruh sanksi hukum karena alasan niat.

Artikel ini mencoba menganalisis kedudukan niat dalam kasus hukum tindak pidana pembunuhan sebagai penerapan kaidah fikih "al-umuru bi maqasidiha", yang nantinya diharapkan dapat mengungkap informasi yang luas tentang bagaimana penerapan kaidah fikih dalam hubungannya dengan kasus-kasus hukum yang lebih luas.

\section{B. Pengertian Niat}

Niat secara etimologi berasal dari bahasa Arab نوي - ينوي - نبة. yang berarti al-qasdu, al-hajah, ${ }^{3}$ yang berarti, maksud, tujuan, hajat. Dalam terminologi syara', niat bermakna "al'azmu ala fi'li syai' taqarruban ila Allah." 4 Artinya adalah keinginan yang kuat untuk melakukan sesuatu sebagai bentuk pendekatan kepada Allah.

Dalam terminologi yang lain, niat didefinisikan sebagai " qasdu al-syai' muqtarinan bi $f i$ 'lih" terjemahan bebasnya lebih kurang adalah "kesengajaan untuk melakukan sesuatu yang kemudian disertakan dengan tindakan hukumnya".

Ibnu Manzur dalam Lisan al-'Arab menyebutkan, niat berasal dari kata nawa dengan masdar niyyah (dengan tasydid) atau niyah (tanpa tasydid), yang berarti qasadahu wa i'tiqadahu, dan definisi niat menurutnya adalah al-wajhu yużhabu fihi, ${ }^{6}$ (orientasi atau visi yang ingin dicapai).

Kamus Besar Bahasa Indonesia, mendefinisikan niat sebagai : 1) maksud atau tujuan suatu perbuatan; 2) kehendak (keinginan dalam hati) akan melakukan sesuatu; 3) janji untuk melakukan sesuatu jika cita-cita atau harapan terkabul; kaul; nazar. ${ }^{7}$ Sementara jika kata niat dikonversi ke dalam bahasa Inggris maka ia berarti intention, plan, aim.

Dari beberapa arti niat di atas, dapat disimpulkan bahwa niat adalah maksud, tujuan, harapan, yang ingin dicapai seseorang dalam melakukan suatu perbuatan, yang tertanam dalam hatinya, dan terimplementasi dalam tindakannya.

\section{Kaidah Fikih tentang Niat}

Kaidah Fikih adalah adalah rumusan dasar hukum yang disusun dalam kata-kata yang ringkas tapi memuat cakupan dalil-dalil hukum yang luas untuk menjawab suatu permasalahan hukum. kaidah berasal dari bahasa Arab yaitu Qä'idah yang berarti asas, dasar atau pondasi. ${ }^{8}$

\footnotetext{
2 Ibnu Nujaim, Al-Asybah wa Al-Nazair, (Beirut : Dar al-Kitab al-Ilmiyyah, 1999), h. 17

${ }^{3}$ Sa'di Abu Habib, Al-Qamus Al-Fiqhi Lughotan wa Istilahan (Damaskus: Dar al-Fikri, 1988)., h. 364

${ }^{4}$ Ibid., h. 36.

${ }^{5}$ Ibid.

${ }^{6}$ Jamaluddin Ibnu Manzur, Lisanu Al-’Arab(Beirut: Dar Sadir, 1414)., juz 5 h.347

${ }^{7}$ Tim Penyusun Kamus Pusat Bahasa, Kamus Bahasa Indonesia, (Jakarta : Pusat Bahasa, 2008), h. 1074

8 Al-Raghib Al-Isfahani, Al-Mufradat fi Garibi Al-Qur'an, Tahqiq Muhammad Sayyid Kailani (Mesir: Mushtafa Al-Babiy Al-Halabiy, 1961).
} 
Dalam bentuk plural disebut Qawā'id yang bermakna asas dan pondasi sesuatu, baik secara zahir ataupun maknawi.

Secara terminologi kaidah fikih didefinisikan oleh Al-Nadwi dalam dua definisi :

1. Hukum syar'i yang termuat dalam ketentuan hukum yang mayoritas, dapat difahami darinya hukum-hukum yang berada dalam cakupannya. ${ }^{9}$

2. Dasar-dasar umum fikih yang memuat hukum-hukum syariat secara umum pada berbagai kajian dalam permasalahan hukum yang mencakup tema-tema di bawahnya. ${ }^{10}$

Kaidah-kaidah fikih dibagi kepada dua kategori, yaitu kaidah pokok (kulliy) dan kaidah cabang (juz'iy) yang merupakan turunannya. Salah satu kaidah fikih yang populer tentang niat adalah adalah:

$$
\text { “semua urusan tergantung niat dan tujuannya". }
$$

Ibnu Nujaim merumuskan pula sebuah kaidah lain tentang niat :

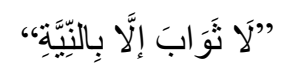

"tidak ada pahala kecuali dengan niat". 11 ia mengatakan bahwa dua kaidah ini masih termasuk dalam pembahasan tentang niat.

Kaidah ini termasuk salah satu kaidah yang sangat penting dalam kajian fikih Islam. Yang menjadi landasan hukum dari kaidah ini adalah hadis Nabi SAW

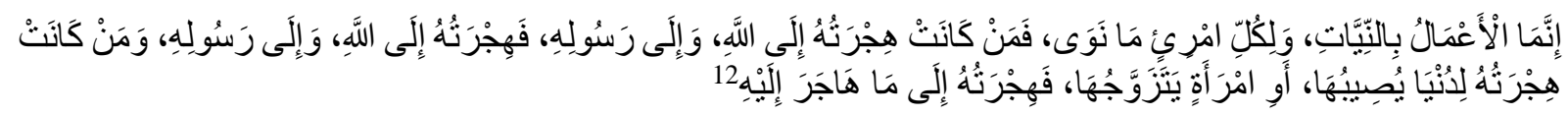

"Sesungguhnya setiap perbuatan itu hanya diberikan nilai terkait dengan niatnya, dan setiap orang hanya akan dibalas sesuai apa yang diniatkannya, jika niat hijrahnya karena Allah dan RasulNya, maka hijrahnya dinilai karena Allah dan RasulNya. Namun jika niat hijrahnya karena berorientasi pada dunia, atau sebab wanita yang ingin dinikahinya, maka ia akan mendapatkan hanya apa yang diniatkannya."

Selain hadis di atas, landasan hukum dari kaidah fikih ini juga dapat dirujuk dalam Al-Qur'an dan Sunnah.

1. Al-Qur'an

a. Q.S. An-Nisa' ayat 100

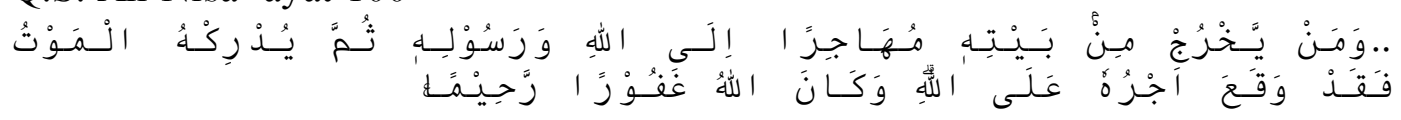

...Barangsiapa keluar dari rumahnya dengan maksud berhijrah karena Allah dan Rasul-Nya, kemudian kematian menimpanya (sebelum sampai ke tempat yang dituju), maka sungguh, pahalanya telah ditetapkan di sisi Allah. Dan Allah Maha Pengampun, Maha Penyayang.

\footnotetext{
${ }^{9}$ Alî Ahmad al-Nadwî, al-Qawâ'id al-Fiqhiyah (Damaskus: Dâr al-Qalam, 1994)., h. 43

${ }^{10}$ Ibid., h. 45

${ }^{11}$ Ibnu Nujaim, Al-Asybah wa Al-Nazair, (Beirut : Dar al-Kitab al-Ilmiyyah, 1999), h. 17

12 Ibnu Majah, Sunan Ibnu Majah, Maktabah Syamilah (Beirut: Dar Al-Jail, 1418). Hadis ke 4227 juz 2, h. 1413 lihat juga : Muhammad bin Ismail Al-Bukhari, Șahih Al-Bukhari, Maktabah Syamilah (Damaskus: Dar Tauq Al-Najah, 1422)., h. 6
} 
Ayat ini menunjukkan pentingnya niat seseorang, saat ia sudah berniat untuk berhijrah karena Allah, ternyata ia mati sebelum sempat beramal dengan sempurna, itu tidak mengurangi pahala dan kedudukannya di sisi Allah SWT.

b. Al-Bayyinah ayat 5

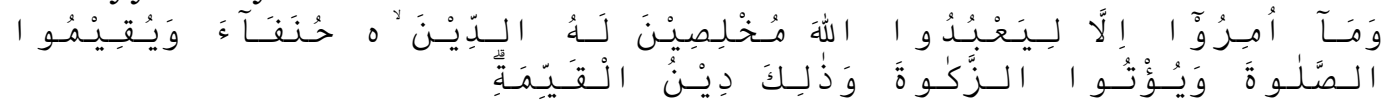

"Padahal mereka hanya diperintah menyembah Allah dengan ikhlas menaati-Nya semata-mata karena (menjalankan) agama, dan juga agar melaksanakan salat dan menunaikan zakat; dan yang demikian itulah agama yang lurus (benar)."

Ayat ini mengungkapkan bahwa Allah memerintahkan manusia untuk beribadah kepada Nya dengan didasarkan pada niat yang ikhlas semata-mata karena Allah.

c. Al-Baqarah ayat 225

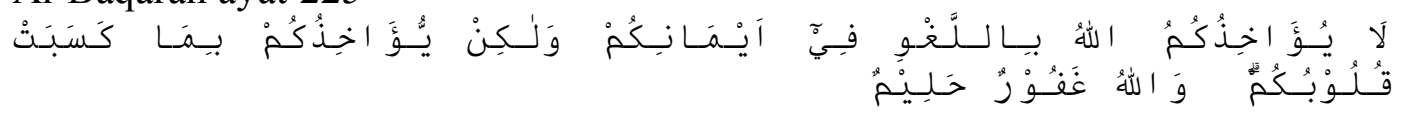

"Allah tidak menghukum kamu karena sumpahmu yang tidak kamu sengaja, tetapi Dia menghukum kamu karena niat yang terkandung dalam hatimu. Allah Maha Pengampun, Maha Penyantun."

Ayat ini mengandung pesan bahwa Allah menilai maksud yang terkandung di dalam hati, meskipun berbeda dengan apa yang diucapkannya.

d. Al-Ahzab ayat 5

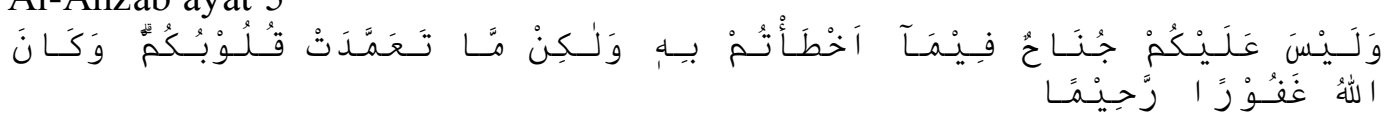

“...Dan tidak ada dosa atasmu jika kamu khilaf tentang itu, tetapi (yang ada dosanya) apa yang disengaja oleh hatimu. Allah Maha Pengampun, Maha Penyayang".

Ayat ini menegaskan bahwa Allah hanya memberikan sanksi hukum terhadap perbuatan hukum yang didasarkan kepada unsur kesengajaan, adapun disebabkan kesalahan maka Allah memberikan peluang kemaafan.

2. Hadis

Selain dijelaskan oleh Al-Qur'an, pentingnya kedudukan niat juga ditegaskan dalam hadis-hadis nabi, di antaranya :

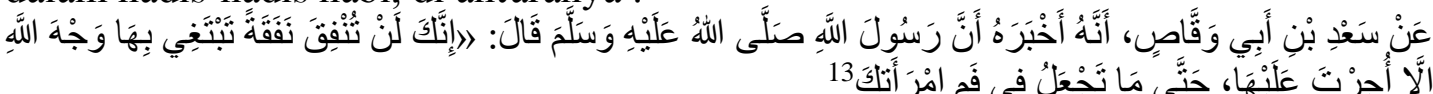

"Sesungguhnya tidaklah engkau mengeluarkan hartamu untuk berinfaq karena mencari keridaan Allah melainkan akan diberikan balasan karenanya, hingga nafkah yang engkau berikan kepada istrimu."

Dan dari hadis Ibnu Mas'ud dalam Musnad Ahmad berbunyi

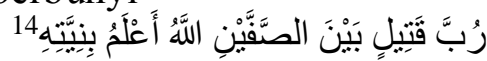

"Berapa banyak golongan yang berperang, sedang Allah yang Maha Tahu tentang niatnya."

${ }^{13}$ Al-Bukhari, Sahih Al-Bukhari., h. 20

${ }^{14}$ Ahmad bin Hanbal, Musnad Ahmad bin Hanbal (t.tp: Muassasah Al-Risalah, 2001). Juz 6, h. 316 


\section{"Allah akan membangkitkan manusia kelak atas niat-niat mereka".}

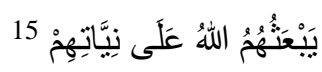

Dari dalil-dalil yang tertuang dalam Al-Qur'an dan Hadis di atas, dapat dilihat pentingnya kedudukan niat dalam tindakan dan perbuatan seseorang, Beberapa poin penting yang dapat dipetik dari dalil-dalil di atas antara lain :

1) Setiap tindakan hukum terkait erat dengan niat atau maksud dan tujuan awalnya.

2) Posisi niat terletak di dalam hati

3) Niat merupakan kunci diterima atau ditolaknya amalan manusia

4) Perbuatan baik harus didasarkan niat ikhlas karena Allah

5) Perbuatan buruk akan diberikan sanksi melihat dari unsur kesengajaannya.

\section{Penerapan Kaidah Fikih Tentang Niat Dalam Tindak Pidana Pembunuhan}

Dari kaidah fikih dan dalil-dalil hukum dari Al-Qur'an dan hadis di atas, dapat difahami bahwasanya niat memiliki kedudukan penting dalam tindakan hukum seorang mukallaf.

Secara lebih luas, dalam artikel ini ingin dilihat penerapan kaidah fikih tentang niat tersebut diaplikasikan dalam kasus-kasus hukum tindak pidana. Dalam hal ini akan dilihat dalam dua perspektif, hukum Islam (jinayah) dan hukum umum (pidana).

1. Niat dalam hukum jinayah Islam

Merujuk kepada literat ur fikih Islam, kajian tentang tindak pidana masuk dalam pembahasan tentang jinayah. Secara etimologi jinayah dikonotosikan sebagai jarimah, yaitu al-żanbu au al-mà siyah ${ }^{16}$ (kejahatan dan kemaksiatan).

Secara terminologi, pengertian jinayah dibagi menjadi dua, definisi umum dan definisi khusus. Jinayah dalam definisi umum diartikan sebagai setiap tindakan yang diharamkan secara syari'at, baik itu tindakan hukum menghilangkan nyawa, harta atau yang lainnya. ${ }^{17}$ Sedangkan menurut pengertian kedua dalam terminologi para ahli fikih, jinayah adalah term khusus yang berkaitan dengan menghilangkan nyawa manusia atau organ tubuhnya, yaitu membunuh, melukai, mencederai dsb. ${ }^{18}$ Sehingga dalam bahasan fikih tema tentang tindak pidana masuk ke dalam tema jinayah (pidana), al-jarăḥ (melukai), atau al-dimā' (menumpahkan darah). ${ }^{19}$

Berkaitan dengan tema niat dalam tindak pidana, salah satu yang dibicarakan adalah tentang kasus hukum pembunuhan. Dalam hukum fikih, pembunuhan yang dikaitkan dengan adanya unsur al-qașdu (adanya maksud, niat atau kesengajaan) diklasifikasikan kepada tiga hal :

a. 'amdun atau pembunuhan sengaja

\footnotetext{
${ }^{15}$ Muslim bin Al-Hajjaj, Șahih Muslim, Maktabah Syamilah (Beirut: Dar Ihya al-Turats Al-'Arabi, t.t.). hadis ke 2884, Juz 4 h. 2210, lihat juga : Al-Bukhari, Sahih Al-Bukhari. Juz 3, h. 65., Musnad Abu Daud hadis ke 1716 Juz 3 h. 184, Musnad Ahmad, hadis 24739, Juz 41 h. 258., Sahih Muslim, Sunan Ibnu Majah hadis ke 4229, juz 2 h. 1414., dan Sunan Al-Tirmizi hadis ke 2171, juz 4, h. 39.

${ }^{16}$ Wahbah Zuhaily, Al-Fiqhu Al-Islami wa Adillatuh, vol. 6 (Damaskus: Dar al-Fikri, 1985)., h. 215

${ }^{17}$ Ibid.

${ }^{18}$ Ibid.

19 Ibid. Imam Hanafi membahasnya dalam tema 'kitab al-jinayah', sementara Imam Syafii i mengemukakannya dalam tema pembahasan 'kitab al-jarah' dan Imam Malik membahasnya dalam judul 'kitab al-dima'..
} 
Yaitu pembunuhan yang dilakukan dengan unsur kesengajaan dengan menggunakan senjata seperti pedang, pisau, benda tajam, api, batu atau alat apa saja yang memang lazimnya digunakan untuk membunuh. ${ }^{20}$

Imam Hanafi mengatakan bahwa unsur kesengajaan atau niat adalah suatu hal yang tersembunyi, dan tidak dapat diketahui kecuali ada bukti yang mendukungnya, yaitu penggunaan alat yang bisa digunakan untuk membunuh, maka alat ini dijadikan sebagai dalil atau bukti adanya al-qașdu atau unsur kesengajaan. ${ }^{21}$

Sanksi hukum terhadap pembunuhan sengaja terbagi menjadi dua macam, sanksi hukum asli dan sanksi hukum pengganti.

Sanksi hukum asli bagi pembunuhan sengaja ialah pelaku dikenakan hukuman qisas, yaitu pembalasan setimpal terhadap pelaku pembunuhan sesuai dengan perbuatannya, atau dihukum mati. ${ }^{22}$

Dasar hukum pelaksanaan qisas ini terdapat dalam Al-Qur'an maupun hadis, di antaranya firman Allah dalam Q.S Al-Baqarah ayat 178 :

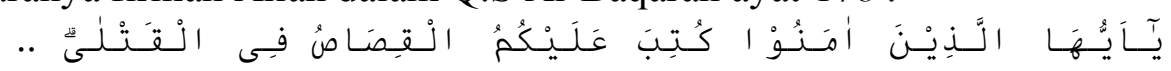

“Wahai orang-orang yang beriman! Diwajibkan atas kamu (melaksanakan) qisas berkenaan dengan orang yang dibunuh....

Sanksi hukum kedua bagi pembunuhan sengaja yaitu sanksi hukum pengganti, sanksi ini dikenakan kepada pelaku apabila hukuman qisas tidak dilaksanakan sebab perbuatannya mendapatkan kemaafan dari wali korban pembunuhan, atau si pembunuh meninggal dunia, maka sanksi hukum penggantinya adalah membayar diyat, atau dikenakan hukuman ta'zir. ${ }^{23}$

b. Syibh 'amdin atau menyerupai sengaja

Yaitu adanya unsur kesengajaan dalam melakukan tindakan pemukulan tapi tidak bermaksud melakukan pembunuhan, seperti menggunakan tongkat atau kayu dengan niat untuk memberi pelajaran, kemudian korban tersebut tewas. ${ }^{24}$

Sanksi hukum terhadap pembunuhan jenis ini ada dua:

Pertama, diyat al-mughallazah. yaitu pembayaran tebusan terhadap keluarga korban senilai serat us ekor unta, dapat dibayarkan dalam tempo maksimal 3 tahun. ${ }^{25}$

Kedua, kafarat. Yaitu memerdekakan seorang budak perempuan yang mukmin, atau jika tidak terpenuhi maka berpuasa selama dua bulan berturutturut. ${ }^{26}$

c. Khata'atau pembunuhan karena kesalahan

Yaitu pembunuhan yang terjadi tanpa unsur kesengajaan dalam penyerangan (bukan pada perbuatan atau tidak dimaksudkan untuk menyerang

${ }^{20}$ Ibid., h. 221

${ }^{21}$ Ibid.

${ }^{22}$ Ibid., h. 261

${ }^{23}$ Pembahasan tentang diyat dan ta'zir ini cukup panjang, pembaca dapat merujuk lebih lanjut dalam Zuhaily, Al-Fiqhu Al-Islami wa Adillatuh., h. 298

${ }^{24}$ Ibid

${ }^{25}$ Ibid., h. 316 pembayaran diyat terhadap pembunuhan semi sengaja ini diambil dari harta pelaku pembunuhan dan dibantu oleh pihak keluarga pembunuh.

${ }^{26}$ Ibid., h. 327 
manusia), seperti hendak melempar binatang, tapi terkena seseorang yang kemudian mati. ${ }^{27}$

Sanksi hukum terhadap pembunuhan jenis ini adalah pembayaran diyat dan kafarat. ${ }^{28}$ Sebagaimana dijelaskan dalam Q.S. Al-Nisa' ayat 92

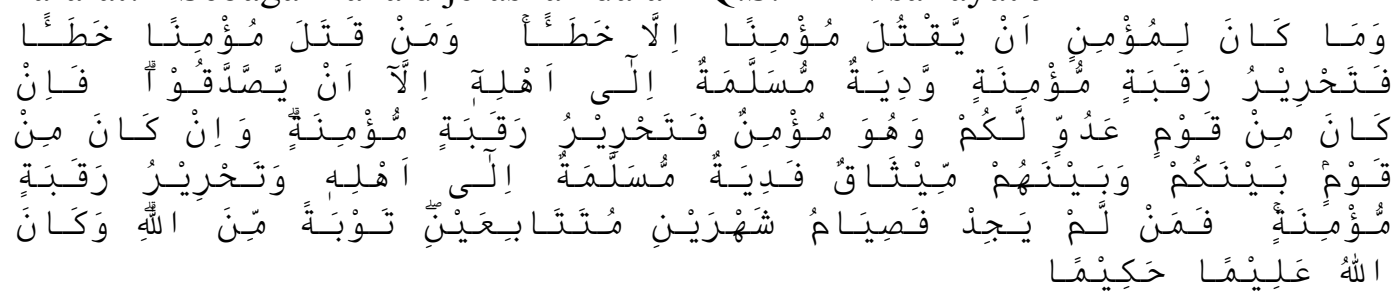

"Dan tidak patut bagi seorang yang beriman membunuh seorang yang beriman (yang lain), kecuali karena tersalah (tidak sengaja). Barangsiapa membunuh seorang yang beriman karena tersalah (hendaklah) dia memerdekakan seorang hamba sahaya yang beriman serta (membayar) tebusan yang diserahkan kepada keluarganya (si terbunuh itu), kecuali jika mereka (keluarga si terbunuh) membebaskan pembayaran. Jika dia (si terbunuh) dari kaum yang memusuhimu, padahal dia orang beriman, maka (hendaklah si pembunuh) memerdekakan hamba sahaya yang beriman. Dan jika dia (si terbunuh) dari kaum (kafir) yang ada perjanjian (damai) antara mereka dengan kamu, maka (hendaklah si pembunuh) membayar tebusan yang diserahkan kepada keluarganya (si terbunuh) serta memerdekakan hamba sahaya yang beriman. Barangsiapa tidak mendapatkan (hamba sahaya), maka hendaklah dia (si pembunuh) berpuasa dua bulan berturutturut sebagai tobat kepada Allah. Dan Allah Maha Mengetahui, Mahabijaksana."

2. Niat dalam hukum pidana

Dalam hukum atau ilmu hukum terdapat beberapa istilah yang sepadan dengan kaidah al-umuru bi maqasidiha. Di antaranya adalah niat, mens rea, opzet, dan delik dolus.

a. Niat

Istilah niat tercantum sebanyak 12 kali dalam KUHP, yaitu pasal 5 ayat 1,29 Pasal 87, pasal 111, pasal 111 bis, pasal $119,{ }^{30}$ pasal $165,{ }^{31}$ pasal 342, pasal 464.

b. Mens rea

Yang dimaksud dengan Mens rea adalah intent to commit the act; guilty mind atau maksud untuk melakukan tindak kejahatan. ${ }^{32}$ pada negara dengan sistem hukum common law dikenal sebuah maxim yang berbunyi "actus non facit reum nisi mens sit rea" (suatu perbuatan tidak membuat seseorang bersalah, kecuali dengan sikap batin yang salah). ${ }^{33}$ Curzon $^{34}$ sebagaimana dikutip oleh Chairul Huda mengatakan, "the maxim draw attention two essential element of crime, the physical element (actus reus) and the mental element (mens rea). Tindak

${ }^{27}$ Ibid., h. 223

${ }^{28}$ Ibid., 328

${ }^{29}$ pasal 5 ayat 1 berbunyi : Mencoba melakukan kejahatan dipidana, jika niat untuk itu telah ternyata dari adanya permulaan pelaksanaan, dan tidak selesainya pelaksanaan itu, bukan semata-mata disebabkan karena kehendaknya sendiri

30 Terdapat 3 kata niat

31 Terdapat 3 kata niat

32 Sindikat, Kamus hukum terlengkap- 11.000 istilah bahasa Inggris \& Belanda.pdf, diunduh dari : https://www.academia.edu/16083005/Kamus_Hukum_Terlengkap-

_11.000_istilah_bahasa_Inggris_and_Belanda, diakses tanggal 21 November 2019 pukul 21.34 WIB

33 Zainal Abidin Farid, Hukum Pidana 1, (Jakarta : Sinar Grafika, , 2014), h. 35.

34 L.B. Curzon, Criminal Law, (London : Pitman Publishing, 1997), h. 20 
pidana terdiri dari dua unsur utama, yaitu unsur fisik (actus reus) dan unsur mental(mens rea). ${ }^{35}$

c. Opzet

Opzet (kesengajaan atau intent) dalam doktrin hukum pidana dikenal ada tiga bentuk :

1) Opzet als oogmerk atau kesengajaan sebagai maksud atau tujuan. Artinya orang yang melakukan perbuatan itu telah memaksudkan terjadinya perbuatan itu. ${ }^{36}$

2) Opzet bij zekerheidbewustzijn atau kesengajaan sebagai kepastian. Bahwa oleh perbuatannya di samping akibat yang dimaksudnya, akan terjadi suatu akibat lain. ${ }^{37}$

3) Opzet bij mogelijkheidbewustzijn atau kesengajaan sebagai kemungkinan. Kesengajaan di sini ditujukan kepada perbuatannya; atau pada akibat dari perbuatan itu, atau pada elemen-elemen lain dari norma pidana yang besangkutan. jadinya juga perbuatan itu sendiri harus telah dikehendaki. ${ }^{38}$

d. Delik dolus

Delik dolus adalah delik yang dilakukan pelakunya dengan sengaja, yaitu tindak pidana yang dilakukan oleh pelakunya dengan penuh kesadaran atas dilakukannya tindak pidana tersebut, dan dengan sungguh-sungguh mengharapkan perbuatannya akan menghasilkan tujuan dari dilakukannya tindak pidana tersebut. ${ }^{39}$

Lawan dari delik dolus adalah delik culpa, yaitu delik yang dilakukan oleh pelakunya dengan tidak sengaja, tetapi perbuatan tersebut karena kealpaan pelakunya. Pada delik culpa, pelaku sama sekali tidak pernah berkeinginan akan terbunuhnya orang tersebut sebagai akibat perbuatannya. ${ }^{40}$

Dari istilah-istilah hukum pidana di atas yang berkaitan dengan penerapan kaidah fikih tentang niat, terdapat pembahasan yang cukup luas dan tidak mungkin dijabarkan pada artikel ini, penulis mencoba mempersempit bahasan dengan kedudukan niat dalam tindak pidana pembunuhan.

Merujuk kepada KUHP buku kedua tentang kejahatan, pada bab XIX Kejahatan Terhadap Nyawa, unsur kesengajaan disebutkan dalam pasal 338 yang berbunyi "Barang siapa dengan sengaja merampas nyawa orang lain, diancam karena pembunuhan dengan pidana penjara paling lama lima belas tahun".

Selain unsur niat atau al-qasdu (kesengajaan), dalam KUHP terdapat tambahan istilah "rencana dalam pembunuhan"41 disebutkan pada Pasal 340 "Barang siapa dengan sengaja dan dengan rencana terlebih dahulu merampas nyawa orang lain, diancam karena pembunuhan dengan rencana, dengan pidana mati atau pidana penjara seumur hidup atau selama waktu tertentu, paling lama dua puluh tahun".

${ }^{35}$ Chairul Huda, 'Dari Tiada Pidana Tanpa Kesalahan' Menuju Kepada 'Tiada Pertanggungjawaban Pidana Tanpa Kesalahan': Tinjauan Kritis Terhadap Teori Pemisahan Tindak Pidana Dan Pertanggungjawaban Pidana, (Jakarta : Kencana, 2011), h. 23

${ }^{36}$ Hasbullah F. Sjawie, Pertanggungjawaban Pidana Korporasi pada Tindak Pidana Korupsi, (Jakarta: Kencana, 2015) h. 19

37 Ibid.

${ }^{38}$ Ibid

${ }^{39}$ Sutan Remy Sjahdeini, Ajaran Pemidanaan: Tindak Pidana Korporasi dan Seluk-Beluknya, Edisi kedua (Depok: Kencana, 2017), h. 49

40 Ibid.

${ }^{41}$ (dalam hukum Islam disebut dengan qatlu al-'amdi sedangkan dalam hukum dianalogikan dengan istilah delik dolus atau opzet) 
Sedangkan pembunuhan karena kesalahan (al-khata'), dijelaskan pada Bab XXI "Menyebabkan Mati Atau Luka-Luka Karena Kealpaan" Pasal 359 yang berbunyi "Barang siapa karena kesalahannya (kealpaannya) menyebabkan orang lain mati, diancam dengan pidana penjara paling lama lima tahun atau pidana kurungan paling lama satu tahun".

Dari dua pasal ini dapat ditemukan kesesuaian antara hukum Islam (jinayah) dan dalam hukum (KUHP) tentang posisi niat dalam tindak pidana pembunuhan, bahwa kedudukan niat berada pada sebab dan pada akibat. Niat pada sebab dapat dilihat pada awal tindakan hukum, yang dinilai dari unsur kesengajaan pelaku, sedangkan niat pada akibat dapat terlihat pada sanksi hukum yang dikenakan kepada pelaku pembunuhan.

Kesesuaian antara hukum Islam dan hukum pidana terkait unsur niat atau kesengajaan dalam tindak pidana pembunuhan dapat dilihat pada bagan berikut ini :

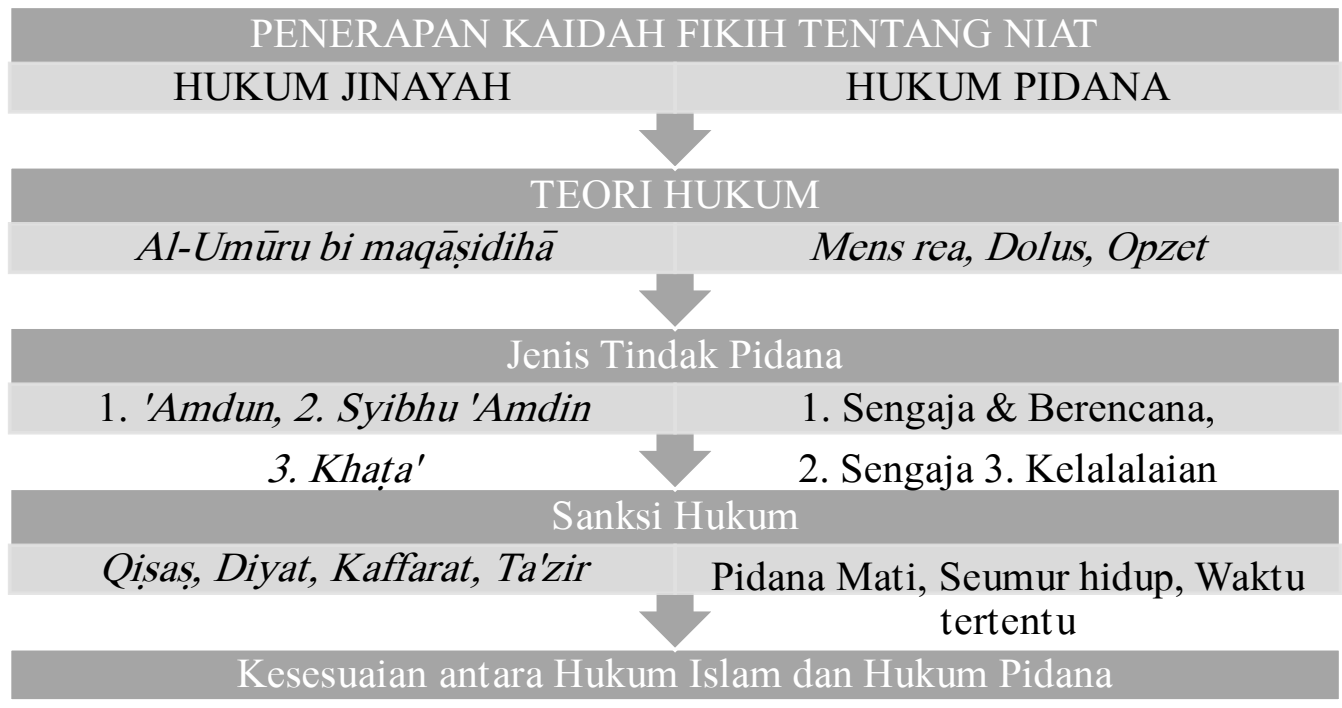

\section{E. Pembuktian Niat dan Unsur Kesengajaan Dalam Putusan Hakim}

Pertanyaan berikutnya yang ingin dijawab adalah bagaimana pembuktian niat atau kesengajaan seseorang dalam putusan-put usan hakim tentang kasus hukum pembunuhan? Untuk menjawab pertanyaan ini, penulis mengambil beberapa sample dari kasus-kasus hukum tentang tindak pidana pembunuhan.

1. Kasus pembunuhan sengaja dan berencana

Dalam putusan Mahkamah Agung Nomor $122 \mathrm{~K} / \mathrm{Pid} / 2019$ tentang tindak pidana pembunuhan yang dilakukan oleh Ndawa Lu, membaca tuntutan pidana penuntut umum yang menyatakan terdakwa terbukti secara sah dan meyakinkan bersalah melakukan tindak pidana "dengan sengaja dan dengan rencana terlebih dahulu merampas nyawa orang lain yakni korban Raki Lawa alias Nenek Dosen". Sebagaimana diatur dan diancam pidana dalam pasal 340 KUHP. ${ }^{42}$

Bukti adanya unsur niat dan kesengajaan dalam perbuatan pelaku didakwakan sebagai "pembunuhan berencana", dengan pokok faktanya bahwa terdakwa mendatangi rumah korban, ketika melihat korban dalam keadaan tidur, pelaku mencekik leher korban dengan menggunakan tangan kirinya, kemudian menutup wajah dan mulut korban sambil menekan kuat-kuat dengan bantal, dan melakukan perkosaan.

\footnotetext{
42 https://putusan.mahkamahagung.go.id/putusan/74d68cbfd41342fabb714fac7d2eb5f8 diakses tanggal 21 November 2019 pukul 13.46
} 
Sanksi hukum yang diajukan oleh penuntut umum berupa pidana mati. Kemudian Pengadilan Negeri memberikan sanksi hukum lebih ringan yaitu pidana penjara selama 20 tahun, sementara dalam pengajuan bandingnya, ternyata Pengadilan tinggi menguatkan putusan Pengadilan Negeri, lalu pemohon mengajukan permohonan kasasi, dan Mahkamah Agung dalam amar putusannya menolak permohonan kasasi dengan menyatakan bahwa putusan Pengadilan Negeri yang dikuatkan Pengadilan Tinggi sudah tepat dan benar bahwa terdakwa telah terbukti secara sah dan meyakinkan bersalah melakukan tindak pidana "Pembunuhan berencana dan perkosaan".

2. Kasus pembunuhan sengaja

Kasus ini diangkat dari putusan Pengadilan Tinggi Kelas I A Khusus Jakarta Utara Nomor : 124 / Pid.B / 2012/ PN. Jkt.Ut. ${ }^{43}$ Bahwa terdakwa Piterson melakukan pembunuhan dengan memasang kawat yang dialiri listrik untuk menjebak pencuri yang sering masuk ke rumah yang sedang dibangunnya. terdakwa menyadari bahwa aliran listrik dapat mengakibatkan orang lain yang terkena aliran listrik tersebut meninggal dunia, namun terdakwa tetap melanjutkan rencananya, ternyata jebakan terdakwa tersebut mendapatkan hasil, yaitu pada keesokan harinya, ada seseorang bernama Koko Saputra dengan posisi orang tidur sedang memegang besi behel/kolom slub yang ada lilitan kabel bendrat beraliran listrik sudah dalam keadaan meninggal dunia.

Dalam kasus ini, pelaku didakwa melanggar pasal 338 "Barang siapa dengan sengaja merampas nyawa orang lain... . Dalam pertimbangan hakim dijelaskan "dengan sengaja", maksudnya adalah kesengajaan sebagai dimaksud/dikehendaki, artinya apabila Terdakwa melakukan perbuatan itu, maka dari niat awalnya matinya korban sebagai tujuan akhir dari perbuatan adalah dikehendaki karena perbuatan itu dilakukan tertuju kepada organ tubuh yang seketika atau dalam waktu yang tidak terlalu lama dapat mematikan atau menyebabkan kematian. Sanksi hukum pidana yang dikenakan adalah penjara selama 7 tahun.

3. Kasus kelalaian yang menyebabkan kematian

Kasus ini berkaitan dengan kelalaian yang mengakibatkan kecelakaan lalu lintas dengan korban meninggal dunia dan luka berat dalam putusan PN Pelalawan nomor 201/Pid.sus-lakalantas/2014/PN Plw. Majelis Hakim menjatuhkan vonis selama 2 tahun penjara. ${ }^{44}$

Unsur kelalaian / kealpaan menurut hakim erat kaitannya dengan sikap kekuranghati-hatian atau kekurangwaspadaan si pelaku, yang seandainya si pelaku bersikap hati-hati, maka peristiwa yang dimaksud tidak akan terjadi.

Dalam putusan ini majelis hakim mengutip pendapat Prof. Moeljatno, SH “Azas-azas hukum Pidana" halaman 201, dikutip dari Van Hamel mengatakan bahwa kealpaan itu mengandung dua syarat yaitu:

1. Tidak mengadakan penduga-duga sebagaimana diharuskan oleh hukum

2. Tidak mengadakan penghati-hati sebagaimana diharuskan oleh hukum. ${ }^{45}$

Dari beberapa contoh kasus hukum tindak pidana di atas, pembuktian unsur niat atau kesengajaan dalam putusan-putusan hakim dapat terlihat dari fakta-fakta hukum

\footnotetext{
${ }^{43} \mathrm{https}: / /$ putusan.mahkamahagung.go.id/putusan/7dc19ec4a18f5c6fc0e7e2a152ebc11b, diakses tanggal 21 November 2019 pukul 13.46.

${ }^{44} \mathrm{https} / / /$ putusan.mahkamahagung.go.id/putusan/7a1698ffe910b5cd4983c7725c715c66, diakses tanggal 21 November 2019 pukul 13.48 .

${ }^{45}$ Ibid.
} 
yang terjadi. Unsur niat dan kesengajaan tersebut juga berpengaruh terhadap sanksi hukum yang dikenakan kepada pelaku.

Setelah melihat penjelasan dari pembahasan tentang niat dan dalil-dalil hukum yang berkaitan dengannya, bahwa untuk memahami tentang penerapan kaidah fikih tentang niat dalam tindak pidana, maka penulis membedakan niat menjadi dua, niat baik dan niat jahat.

\section{Niat Baik}

- Niat baik adalah maksud hati seseorang untuk melakukan suatu perbuatan baik.

- Niat baik (ikhlas karena Allah) adalah syarat untuk diterimanya suatu perbuatan baik.

- Niat baik tidak masuk kedalam kajian hukum jinayah, sebab tidak dapat dan tidak perlu dibuktikan secara hukum, karena hukum hanya menilai perbuatan pada apa yang tampak bukan yang tersembuyi di dalam hati, dan hanya Allah saja yang dapat memberikan penilaian

- Niat baik tidak dapat menjadi alasan untuk melakukan kejahatan.

- Niat baik adalah merupakan ibadah tersendiri (ibadah mustaqillah), dan akan mendapatkan balasan pahala meskipun ia belum melakukan perbuatan baik. Karena niat baik termasuk perbuatan baik itu sendiri. Sesuai dengan hadis dari Ibnu Abbas

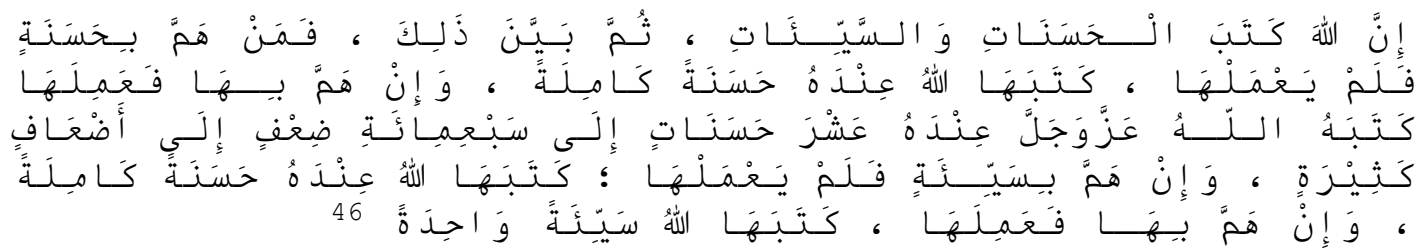

"Sesungguhnya Allâh menulis kebaikan-kebaikan dan kesalahan-kesalahan kemudian menjelaskannya. Barangsiapa berniat melakukan kebaikan namun dia tidak (jadi) melakukannya, Allah tetap menuliskanya sebagai satu kebaikan sempurna di sisi-Nya. Jika ia berniat berbuat kebaikan kemudian mengerjakannya, maka Allah menulisnya di sisi-Nya sebagai sepuluh kebaikan hingga tujuh ratus kali lipat sampai kelipatan yang banyak. Barangsiapa berniat berbuat buruk namun dia tidak jadi melakukannya, maka Allah menulisnya di sisi-Nya sebagai satu kebaikan yang sempurna. Dan barangsiapa berniat berbuat kesalahan kemudian mengerjakannya, maka Allah menuliskannya sebagai satu kesalahan.”

2. Niat Jahat

- Niat jahat adalah adanya unsur kesengajaan ketika seseorang bermaksud untuk melakukan suatu perbuatan buruk atau jahat. Dalam bahasa hukum dikenal istilah mens rea, opzet, atau delik dolus.

- Kesengajaan (al-qasdu) dalam niat jahat dapat dibuktikan dari alat yang digunakan untuk berbuat kejahatan atau dengan fakta-fakta hukum dari tindakan pelaku kejahatan.

- Sanksi hukum terhadap pembunuhan dapat dibedakan dengan ada atau tidaknya unsur kesengajaan dalam perbuatan. Sanksi hukum terhadap tindak pidana dengan unsur kesengajaan lebih berat sebagaimana termaktub dalam KUHP dan putusanputusan hakim.

- Niat jahat diakui sebagai kejahatan jika diikuti dengan perbuatan jahat.

${ }^{46}$ Bukhari, Sahịh.., hadis ke 6491, juz. 8, h. 103 
Sesuai dengan sabda Rasulullah Shallallahu 'alaihi wa sallam,

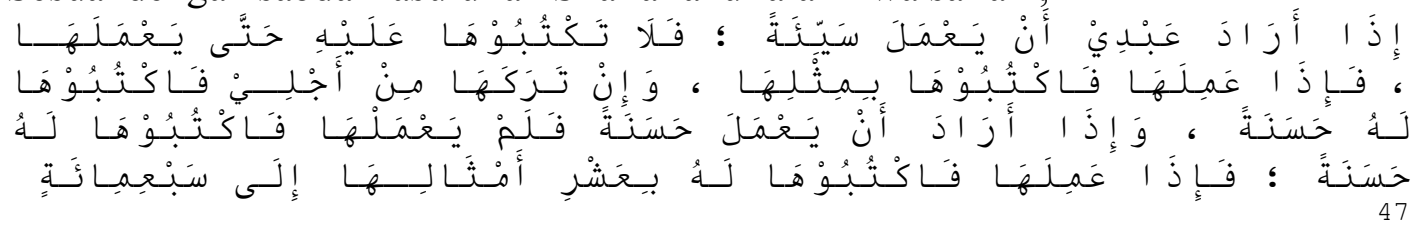

"Jika hamba-Ku berniat melakukan kesalahan, maka janganlah kalian menulis kesalahan itu sampai ia (benar-benar) mengerjakannya. Jika ia sudah mengerjakannya, maka tulislah sesuai dengan perbuatannya. Jika ia meninggalkan kesalahan tersebut karena Aku, maka tulislah untuknya satu kebaikan. Jika ia ingin mengerjakan kebaikan namun tidak mengerjakannya, tulislah sebagai kebaikan untuknya. Jika ia mengerjakan kebaikan tersebut, tulislah baginya sepuluh kali kebaikannya itu hingga tujuh ratus (kebaikan).

\section{F. Kesimpulan}

Dari uraian pembahasan di atas, dapat ditarik beberapa kesimpulan tentang penerapan kaidah fikih al-umuru bi maqasidiha yang berkaitan dengan kedudukan niat dalam tindak pidana pembunuhan.

1. Kedudukan niat dalam tindak pidana berada pada sebab dan pada akibat. Niat pada sebab dapat dilihat pada awal tindakan hukum, yang dinilai dari unsur kesengajaan pelaku, sedangkan niat pada akibat dapat terlihat pada sanksi hukum yang dikenakan kepada pelaku pembunuhan.

2. Niat terbagi kepada dua macam, niat baik dan niat jahat. Yang termasuk dalam kajian hukum tindak pidana hanyalah niat jahat. Sementara niat baik masuk ke dalam kajian hukum tentang ibadah.

3. Pembuktian niat atau unsur kesengajaan dalam putusan-putusan hakim tentang tindak pidana pembunuhan dilihat dari fakta-fakta hukum yang terjadi.

4. Unsur niat juga berpengaruh terhadap putusan hakim, pengaruhnya terlihat dalam sanksi hukum, pelaku tindak pidana dengan unsur kesengajaan (al-qasdu) dikenakan sanksi hukum yang lebih berat daripada pembunuhan akibat kelalaian yang menyebabkan kematian.

5. Penerapan Kaidah Fikih tentang Niat dalam kajian hukum jinayah Islam dan hukum pidana terdapat kesesuaian dalam jenis tindak pidana dan sanksi hukum.

\footnotetext{
${ }^{47}$ Bukhari, Sahịh..., hadis ke 7501, juz. 9, h. 144
} 


\section{DAFTAR PUSTAKA}

\section{A. BUKU}

Bukhari, Muhammad bin Ismail Al-. Șahih Al-Bukhari. Maktabah Syamilah. Damaskus: Dar Tauq Al-Najah, 1422

Curzon, L.B. Criminal Law, London : Pitman Publishing, 1997

Farid, Zainal Abidin. Hukum Pidana 1, Jakarta : Sinar Grafika, , 2014

Habib, Sa'di Abu. Al-Qamus Al-Fiqhi Lughatan wa Istilahan. Damaskus: Dar al-Fikri, 1988.

Hanbal, Ahmad bin. Musnad Ahmad bin Hanbal. t.tp: Muassasah Al-Risalah, 2001.

Huda, Chairul. 'Dari Tiada Pidana Tanpa Kesalahan' Menuju Kepada 'Tiada Pertanggungjawaban Pidana Tanpa Kesalahan': Tinjauan Kritis Terhadap Teori Pemisahan Tindak Pidana Dan Pertanggungjawaban Pidana, Jakarta: Kencana, 2011

Isfahani, Al-Raghib Al-. Al-Mufradat fi Garibi Al-Qur'an, Tahqiq Muhammad Sayyid Kailani, Mesir: Mushtafa Al-Babiy Al-Halabiy, 1961

Majah, Ibnu. Sunan Ibnu Majah. Maktabah Syamilah. Beirut: Dar Al-Jail, 1418.

Manzur, Jamaluddin Ibnu. Lisanu Al-'Arab. Beirut: Dar Sadir, 1414.

Muslim bin Al-Hajjaj, Șahih Muslim, Maktabah Syamilah, Beirut: Dar Ihya al-Turats Al'Arabi, t.t.

Muslim bin Al-Hajjaj. Șahih Muslim. Maktabah Syamilah. Beirut: Dar Ihya al-Turats Al'Arabi, t.t.

Nadwî, Alî Ahmad al-. al-Qawâ'id al-Fiqhiyah. Damaskus: Dâr al-Qalam, 1994.

Nasa'i, Al. Al-Sunan Al-Kubra, Beirut : Muassasah Al-Risalah, 2001

Nujaim, Ibnu. Al-Asybah wa Al-Nazair, Beirut : Dar al-Kitab al-Ilmiyyah, 1999

Sa'di Abu Habib, Al-Qamus Al-Fiqhi Lughotan wa Istilahan, Damaskus: Dar al-Fikri, 1988

Sjahdeini, Sutan Remy. Ajaran Pemidanaan: Tindak Pidana Korporasi dan Seluk-Beluknya, Edisi kedua, Depok: Kencana, 2017

Sjawie, Hasbullah F. Pertanggungjawaban Pidana Korporasi pada Tindak Pidana Korupsi, Jakarta: Kencana, 2015

Tim Penyusun Kamus Pusat Bahasa, Kamus Bahasa Indonesia, Jakarta : Pusat Bahasa, 2008

Zuhaily, Wahbah Al-. Al-Fiqhu Al-Islami wa Adillatuh. Vol. 6. Damaskus: Dar al-Fikri, 1985.

\section{B. DOKUMEN UNDUHAN}

Sindikat, Kamus hukum terlengkap- 11.000 istilah bahasa Inggris \& Belanda.pdf, diunduh dari https://www.academia.edu/16083005/Kamus_Hukum_Terlengkap_11.000_istilah_bahasa_Inggris_and_Belanda, diakses tanggal 21 November 2019 pukul 21.34 WIB 
Putusan Mahkamah agung Nomor $122 \mathrm{~K} / \mathrm{Pid} / 2019$, diunduh dari : https://putusan.mahkamahagung.go.id/putusan/74d68cbfd41342fabb714fac7d2eb5f8 diakses tanggal 21 November 2019 pukul 13.46

Putusan Pengadilan Tinggi Kelas I A Khusus Jakarta Utara Nomor : 124 / Pid.B / 2012/ PN. Jkt.Ut, diunduh dari https://putusan.mahkamahagung.go.id/putusan/7dc19ec4a18f5c6fc0e7e2a152ebc11b diakses tanggal 21 November 2019 pukul 13.46

Putusan PN Pelalawan nomor 201/Pid.sus-lakalantas/2014/PN Plw diunduh dari: https://putusan.mahkamahagung.go.id/putusan/7a1698ffe910b5cd4983c7725c715c66, diakses tanggal 21 November 2019 pukul 13.48. 